\title{
制振合金を利用した動吸振器の開発
}

\author{
岩田 佳雄 ${ }^{* 1}$ ，小松㟝 俊彦 ${ }^{* 2}$, 浅沼 春彦*2，北山 弘樹 ${ }^{* 2}$
}

\section{Development of dynamic damper using damping alloy}

\author{
Yoshio IWATA ${ }^{* 1}$, Toshihiko KOMATSUZAKI ${ }^{* 2}$, Haruhiko ASANUMA ${ }^{* 2}$ and Hiroki KITAYAMA*2 \\ ${ }^{* 1,{ }^{2}}$ Kanazawa Univ., Faculty of Mechanical Engineering \\ Kakuma-machi, Kanazawa 920-1192 Japan
}

Received: 6 March 2018; Revised: 17 May 2018; Accepted: 2 July 2018

\begin{abstract}
If damping alloy is used as structural material, a structure with high damping performance can be produced and its vibration and noise can be reduced. Damping mechanism of the damping alloy is to convert vibration energy into thermal energy. The damping performance of the damping alloy is not as good as it is used in a dynamic damper. This paper proposes a method of enlarging equivalent loss factor of a damping alloy spring by using a negative spring constant and it is confirmed that the equivalent loss factor of a damping alloy cantilever becomes large by the attraction force of magnet used as the negative spring constant. Optimal design of the dynamic damper which consists of the damping alloy cantilever and a pair of magnets is explained. The vibration suppression effect due to the dynamic damper is demonstrated by means of measuring the compliance and the time history response by impact excitation. The vibration suppression effect depends on the vibrational amplitude due to nonlinearity of the attraction force of magnet but can be sufficiently expected in comparison with the case without the dynamic damper.
\end{abstract}

Keywords : Damping, Dynamic damper, Damping alloy, Optimal design, Nonlinearity

\section{1. 緒言}

制振合金は一般の金属に比べ減衰能力が高く，構造用材料として使用するならば金属材料よりも減衰性能の大 きな構造物を製作することができ，その振動・騒音を低減することが可能となる（前，1989，長松，2008）。制振 合金の減衰機構は内部摩擦によって振動エネルギーを熱エネルギーに換えるものである．このため制振合金の減 衰モデルとして材料減衰を適用するのが一般的であり,このとき減衰性能は損失係数によって表される(五十嵐， 2001). この減衰性能は高分子系の制振材料と比べると小さく, また振幅, 振動数, 温度に依存することが知られ ている.

本報では大同特殊鋼株式会社製の D2052 を使って動吸振器を製作したことについて報告する. これは双晶型の 制振合金で，双晶間の摩擦によって振動エネルギーを吸収するものである。一般に制振合金は動吸振器の減衰要 素として用いるには損失係数が小さく, 動吸振器への適用は困難と考えられ, 実際に動吸振器に用いた例はない ようである，そこで本報では制振合金のばねを持つ 1 自由度系の減哀性能を向上させる方法を提案し，これによ って制振合金から構成される動吸振器が製作可能になることを実証する.

\section{2. 制振合金の減衰性能}

本報では動吸振器のばねダンパ要素として制振合金を使用する。まずは制振合金の減衰性能を調べるため，図

No.18-00124 [DOI: 10.1299/transjsme.18-00124], J-STAGE Advance Publication date : 10 July, 2018

${ }^{* 1}$ 正員，フェロー，金沢大学（广920-1192 石川県金沢市角間町）

*2 正員, 金沢大学

E-mail of corresponding author: iwata@se.kanazawa-u.ac.jp 
1 のように水平面内で振動する片持ちはり系を製作した．後にこれを動吸振器として使用した．厚さ $2 \mathrm{~mm} の$ 制振 合金の板材から長さ $180 \mathrm{~mm}$, 幅 $20 \mathrm{~mm}$ のはりを切り出し,この一端を固定して長さ $150 \mathrm{~mm}$ の片持ちはりを製作, 固定端から $120 \mathrm{~mm}$ の位置に質量 $123 \mathrm{~g}$ の鋼製の錘を固定する. 片持ちはりの先端を弾くことによって自由振動さ せ，はり先端から $5 \mathrm{~mm}$ の点をレーザー変位計にて測定し，はりの振動変位を測定した. 図 1 中の磁石のない場 合の振動変位を図 2 に示寸. この波形の極大值と極小值から得られる p-p 振幅を求め, それらの周期毎の比から 減衰比を算出した (岩田他, 2017). なお最初の極小值は加振の影響が出ていたのでこれを除いた. 求められた減 衰比を 2 倍したものを損失係数の值とし（長松，1993）, p-p 振幅と損失係数の関係を表したものを図 3 に「磁石 なし」の線で示す．図からわかるように振幅が小さくなるにつれて損失係数もわずかに小さくなり，振幅依存性 があることが確認できる.

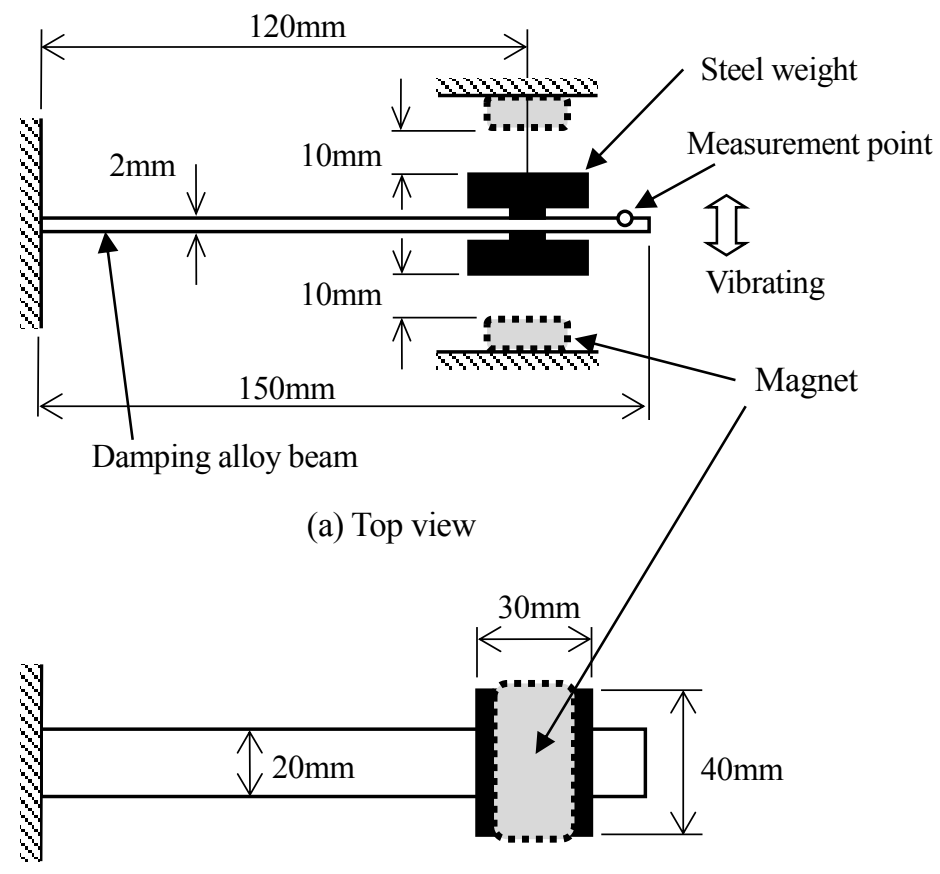

(b) Front view

Fig.1 Cantilever consisting of damping alloy beam and steel weight

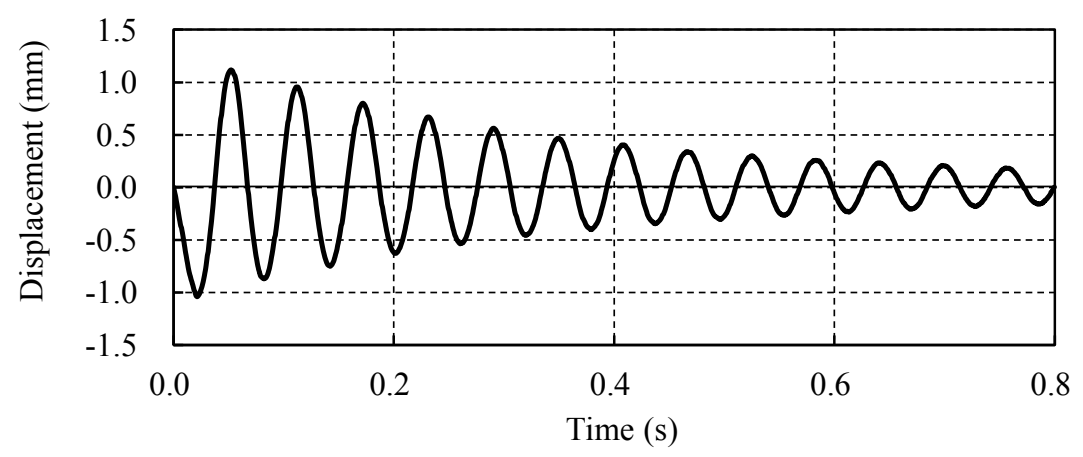

Fig.2 Free vibration wave of damping alloy cantilever 


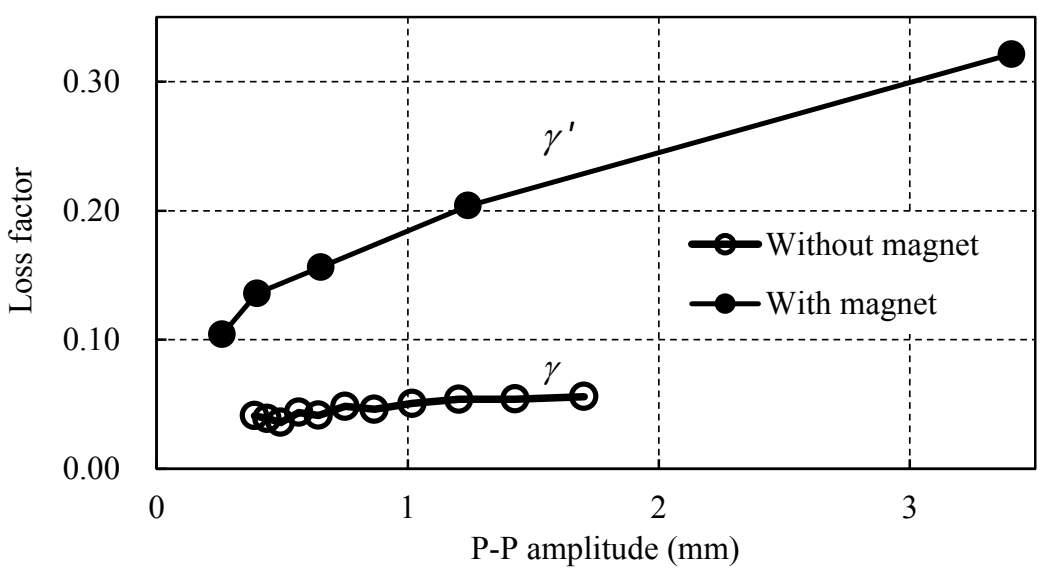

Fig.3 Relationship between loss factor and p-p amplitude. The loss factor of "With magnet" is larger than that of "Without magnet" and the loss factor becomes large with increasing of the p-p amplitude.

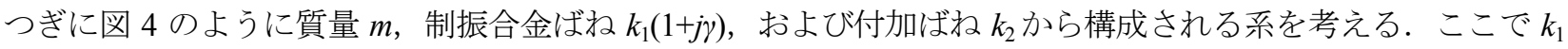
は制振合金ばねのばね定数， $\gamma$ はその損失係数， $k_{2}$ は付加ばねのばね定数である. この系の運動方程式は式(1)の ように表される.

$$
m \ddot{x}+\left(k_{1}+k_{2}\right)\left(1+j \gamma^{\prime}\right) x=0
$$

ここに,

$$
\gamma^{\prime}=\frac{k_{1} \gamma}{k_{1}+k_{2}}
$$

$\gamma^{\prime}$ はこの 1 自由度系の等価損失係数となる. $\gamma^{\prime}$ の式から付加ばね $k_{2}$ を追加すると等価損失係数は小さくなるので 減衰性能も小さくなることがわかる，しかし， $k_{2}$ が負であれば，逆に減衰性能が大きくなることがわかる．この ことを確かめるため図 1 の錘の両側に $10 \mathrm{~mm}$ の間隔をあけて表面磁束約 $4000 \mathrm{G}$ のネオジム磁石を設置し, その吸 引力を負のばねとして使用した．片持ちはり先端を弾いて測定した自由振動波形を図 5 に示寸. 図 2 の波形に比 べ振動が早く減衰し，かつ式(2)のばね定数 $k_{1}+k_{2}$ が小さくなるので振動の周期が長くなることがわかる．最初の 極小值も含めて p-p 振幅の比から等価損失係数 $\gamma^{\prime}$ を求め, p-p 振幅毎の変化を図 3 に「磁石あり」の線で示寸. 磁 石なしの場合に比べて損失係数の值が大きく増えることがわかり，負のばねを設置することによって制振合金の 減衰性能を向上させることが可能となる，なお，磁石の吸引力の非線形性のために錘の振幅が大きいほど吸引力 が強くなり，このとき $\gamma^{\prime} も 一$ 緒に大きくなるが, 振幅が小さくなると急激に小さくなる.したがって「磁石なし」 の場合に比べて等価損失係数の振幅依存性が顕著に現れ，図 3 からもそのことがわかる.

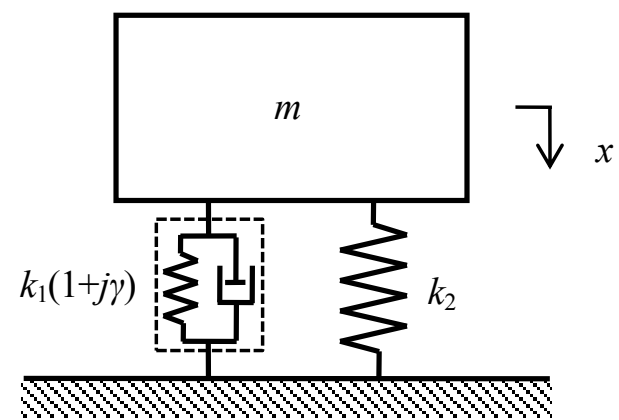

Fig.4 Single degree of freedom system which consists of damping alloy spring $k_{1}(1+j \gamma)$, additional spring $k_{2}$ and mass $m$ 


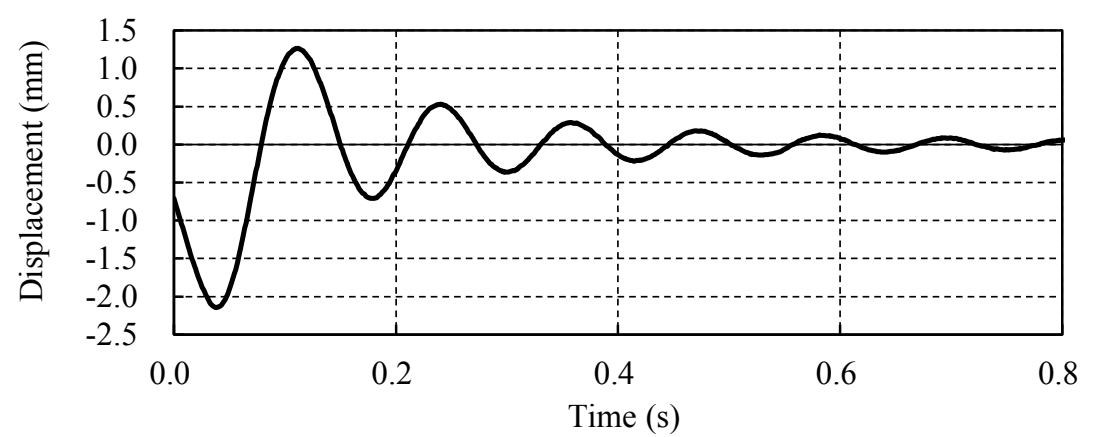

Fig.5 Free vibration wave of cantilever with magnets (Gap 10mm)

後に図 1 の制振合金片持ちはりを 1 自由度系にモデル化してシミュレーションするため, 図 3 において $\mathrm{p}-\mathrm{p}$ 振 幅が約 $1.2 \mathrm{~mm}$ の測定結果の損失係数 $\gamma=0.0539$ を採用する. このときの周期から固有振動数を $16.7 \mathrm{~Hz}$ とした. こ の片持ちはりの質量とばね定数を同定するため，1自由度質量感応法（背戸，松本，1999）を適用する．これは 付加質量を取り付けたときの固有振動数，付加質量なしの固有振動数の両者から質量とばね定数を推定する方法 である. 鍾に $21.8 \mathrm{~g}$ の付加質量を取り付けて測定した固有振動数 $15.5 \mathrm{~Hz}$ を用いると, 質量 $0.135 \mathrm{~kg}$ とばね定数 $1486 \mathrm{~N} / \mathrm{m}$ が決定された. 同様に図 3 から「磁石あり」の p-p 振幅 $1.2 \mathrm{~mm}$ 付近の測定結果の等価損失係数 $\gamma^{\prime}$ は 0.204 , 図 5 からこのときの固有振動数 $7.53 \mathrm{~Hz}$ を決定した.

\section{3. 動吸振器人の応用}

図 4 に示寸 1 自由度系を動吸振器として利用したモデルを図 6 に示寸. 主振動系の質量を $M$, ばね定数を $K$ と おく. また図 4 と同様に動吸振器の質量を $m$, 制振合金ばねのばね定数を $k_{1}$, その損失係数を $\gamma$, 磁石による負 のばね定数を $k_{2}$ とする. 粘性減衰の動吸振器と同じように応答曲線の定点理論を適用し, 最適な動吸振器となる 固有振動数比 $\omega_{n 2} / \omega_{n 1}$ と等価損失係数 $\gamma^{\prime}{ }_{o p t}$ を次式から求めることができる（浦田，竹田，1995）。 $\mu$ は主系と動吸 振器系の質量比である.

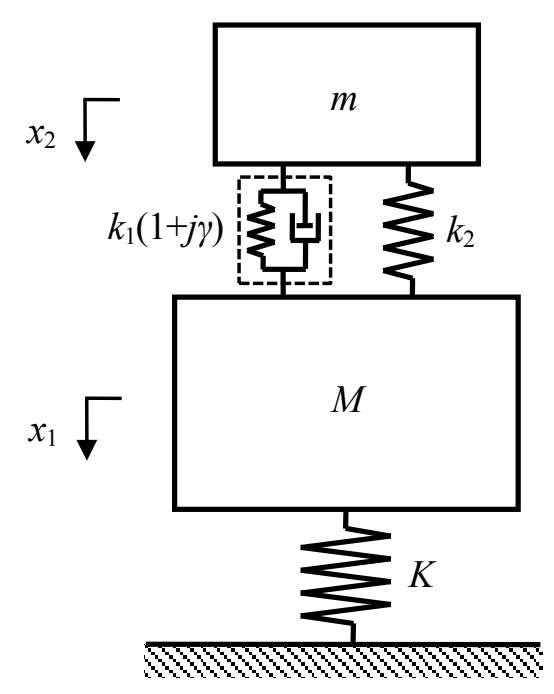

Fig.6 Two degree of freedom system with dynamic damper

$$
\frac{\omega_{n 2}}{\omega_{n 1}}=\frac{1}{1+\mu}, \quad \gamma_{o p t}^{\prime}=\sqrt{\frac{\mu(3+2 \mu)}{2+\mu}}
$$




$$
\omega_{n 1}=\sqrt{\frac{K}{M}}, \quad \omega_{n 2}=\sqrt{\frac{k_{1}+k_{2}}{m}}, \quad \mu=\frac{m}{M}
$$

式(3)と式(4)より，最適な制振合金のばね定数 $k_{1 o p t}$ と付加ばね定数 $k_{2 o p t}$ はつぎのようになる.

$$
\begin{aligned}
& k_{1 o p t}=\frac{\mu K}{\gamma(1+\mu)^{2}} \sqrt{\frac{\mu(3+2 \mu)}{2+\mu}} \\
& k_{2 o p t}=\frac{\mu K}{(1+\mu)^{2}}\left(1-\frac{1}{\gamma} \sqrt{\frac{\mu(3+2 \mu)}{2+\mu}}\right)
\end{aligned}
$$

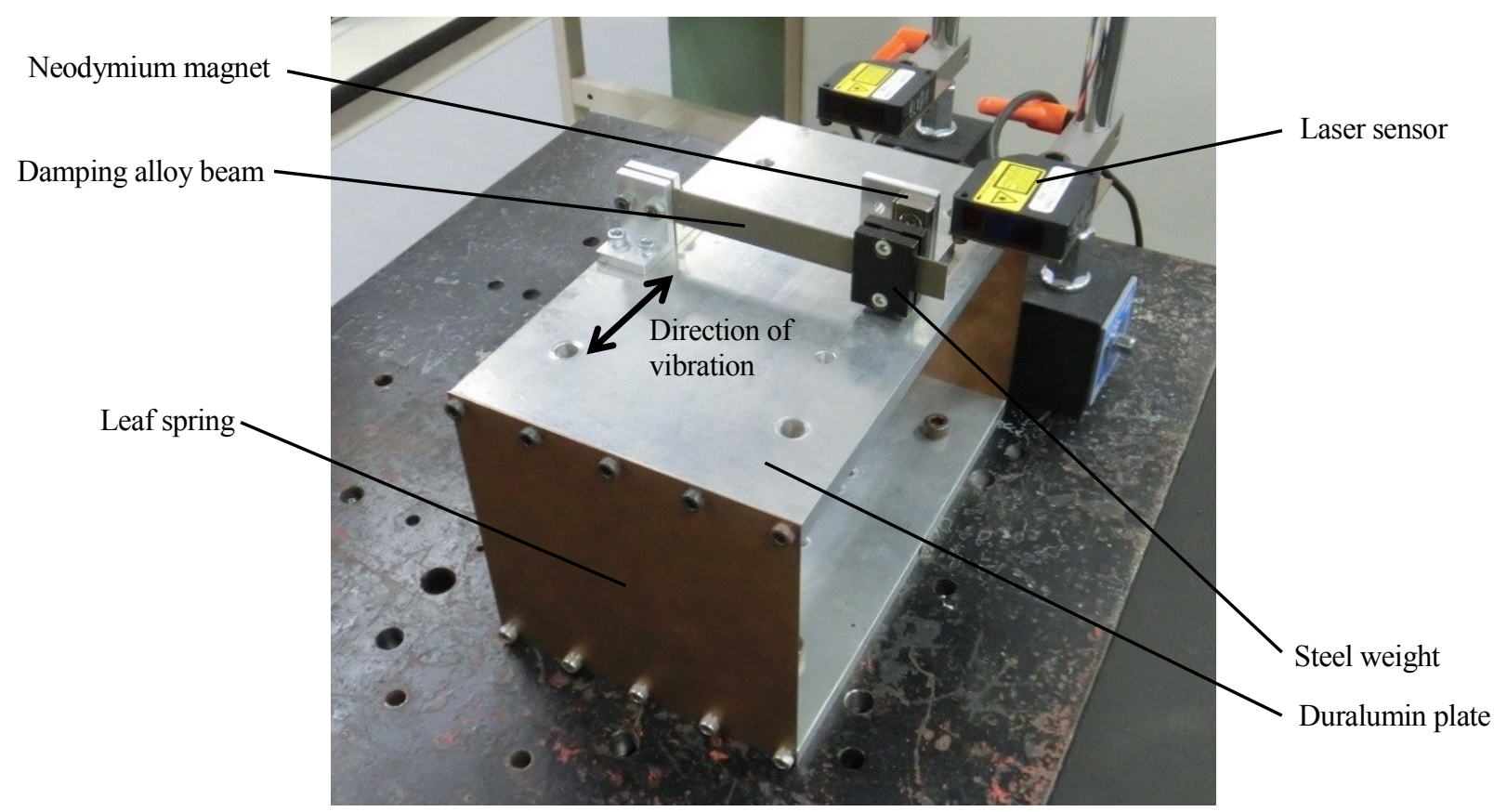

Fig.7 Two degree of freedom system with dynamic damper. Neodymium magnets are installed on both sides of the steel weight (The magnet at the front is removed because the weight can be seen.)

図 1 の片持ちはりと 2 個の磁石を動吸振器として設置した 2 自由度系を製作し，その効果を確かめた．図 7 に その写真を示す．実際には片持ちはりの鍾の両側に磁石を配置したが，錘と磁石の状態を見ることができるよう に写真では手前側の磁石を取り外してある．主系は寸法 $300 \mathrm{~mm} \times 180 \mathrm{~mm}$ ，厚さ $12 \mathrm{~mm}$ のジュラルミン板を，寸法 $180 \mathrm{~mm} \times 172 \mathrm{~mm}$, 厚さ $0.8 \mathrm{~mm}$ の 2 枚のリン青銅板ばねで支えたもので, 写真中の矢印の方向に振動する. 動吸振 器の場合と同様に 1 自由度質量感応法を利用して主系質量 $M$ （片持ちはり固定部と磁石 2 個を含む.）とばね定 数 $K$ を求め, $M=2.33 \mathrm{~kg}, K=6090 \mathrm{~N} / \mathrm{m}$ とした. 片持ちはりの錘と磁石の間のギャップを $9 \mathrm{~mm}, 10 \mathrm{~mm}, 11 \mathrm{~mm}$ と変 え，主系をインパクト加振してコンプライアンスを測定したところ $10 \mathrm{~mm}$ のときが最も振幅のピークが小さくな った．このときのコンプライアンスを，磁石を遠ざけたもの（以後,「磁石なし」と呼ぶ.）と比較して図 8 に示 す．測定の都合で，「磁石なし」の場合には $10 \%$ のクスポネンシャルの空関数を使用し，ギャップ $10 \mathrm{~mm}$ の動 吸振器設置の場合には空関数なしとした．したがって「磁石なし」のコンプライアンスのピークは実際にはもっ と高いものとなっている。「磁石なし」の場合は図 6 において $k_{2}=0$ とした 2 自由度系となり, $8 \mathrm{~Hz}$ 付近に 1 次共 振, $18 \mathrm{~Hz}$ 付近に 2 次共振のピークが現れる. 主系質量 $M=2.33 \mathrm{~kg}$ に対し動吸振器質量は $m=0.135 \mathrm{~kg}$ と小さいので, 主系のみの応答曲線は図 8 (a)の「磁石なし」のものとほとんど変わらず，ピークの振動数がわずかに大きくなる 
程度である. 磁石を配置して動吸振器を構成した場合には $8 \mathrm{~Hz}$ 付近に近接して 2 つのピークが現れ，これが 1 次 と 2 次の共振を示寸. 主系のコンプライアンスの図 8(a)から動吸振器によってピークが十分に小さくなること, 動吸振器のコンプライアンスの図 8(b)から動吸振器が大きく振動して振動エネルギーの吸収が行われることがわ かる. なお, 動吸振器を設置した場合の 2 次のピークの形が丸くなっているのは, 2 次モードでは主系と動吸振 器が逆位相となって振動するためその相対変位が大きくなり, 磁石の吸引力の非線形性の影響が大きく現れたた めと考えられる. 図 8 のコンプライアンス測定時と同程度のインパクトを主系に与えた後の主系と動吸振器の振 動応答を図 9 に示す.「磁石なし」と「磁石あり」の場合の比較から, 動吸振器を付けることによって主系振動が 早く収束することがわかる. 一方, 動吸振器は加振直後においては「磁石なし」以上に大きく振動するが, その 後急速に振動が収束する.

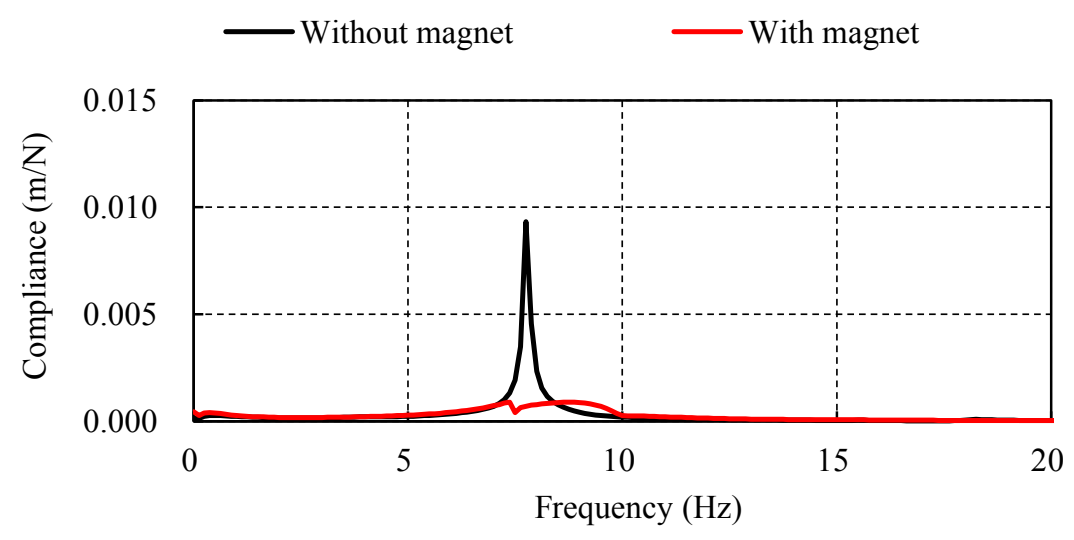

(a) Main system

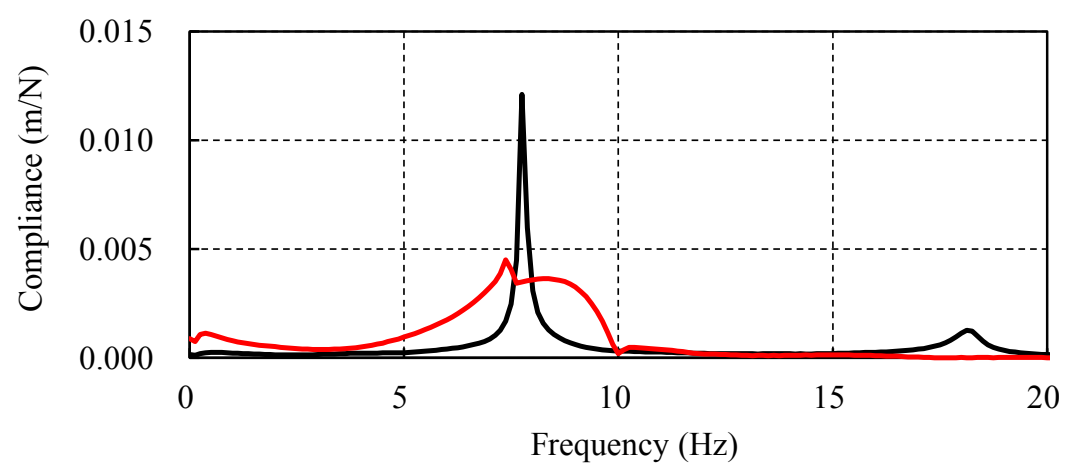

(b) Dynamic damper

Fig.8 Compliance by impact excitation. There are two peaks in the two degree of freedom system without the magnets. The compliance of the main system almost coincides with that of a single degree of freedom system without the dynamic damper. The peak height of main system decreases due to the dynamic damper in figure (a). It is found in figure (b) that the dynamic damper absorbs vibration energy.

図 5 にこの動吸振器単体の自由振動波形を示したが, この図の p-p 振幅 $1.2 \mathrm{~mm}$ 付近の振動数 $7.53 \mathrm{~Hz}$ とその質 量 $0.135 \mathrm{~kg}$ からばね定数 $k_{1}+k_{2}=302 \mathrm{~N} / \mathrm{m}$ を求めることができる. これより $\mathrm{p}-\mathrm{p}$ 振幅 $1.2 \mathrm{~mm}$ 付近の磁石の吸引力によ るばね定数 $k_{2}=-1184 \mathrm{~N} / \mathrm{m}$ が求められる. 以上より磁石のギャップが $10 \mathrm{~mm}$ のときの 2 自由度系のパラメータ值は 表 1 のようになる. また, 主系のパラメータと質量比 $\mu=0.0579$ を用いて式(3), 式(5), 式(6)から算出された最適 な等価損失係数 $\gamma^{\prime}{ }_{\text {opt }}$ と最適ばね定数 $k_{1 o p t}, k_{2 o p t}$ を表 1 に示す. 


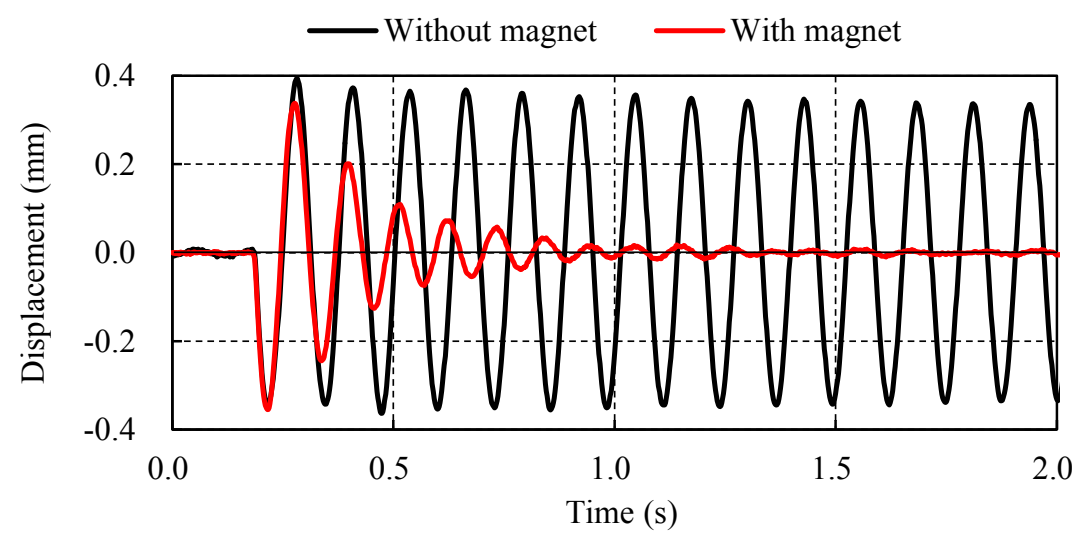

(a) Main system

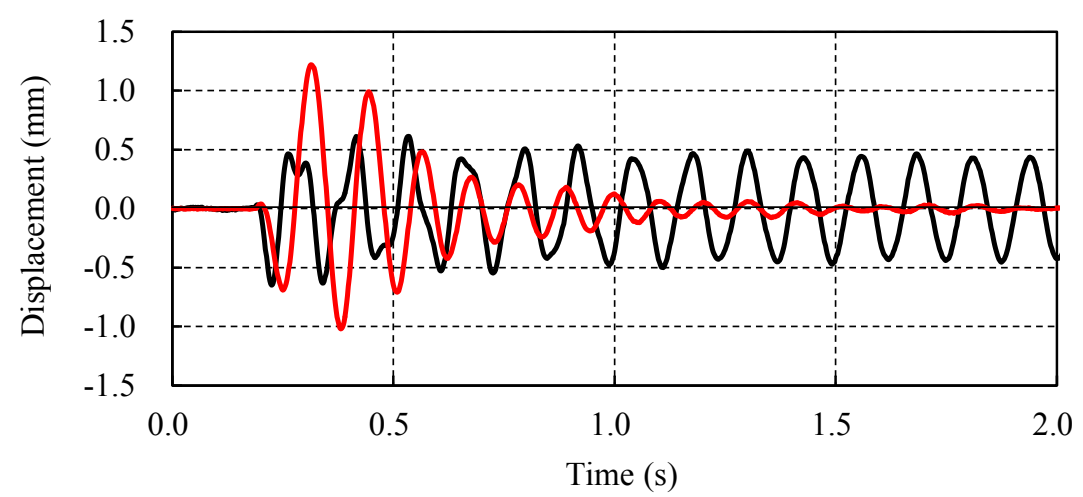

(b) Dynamic damper

Fig.9 Impact response. The vibration of main system with magnet is damped quicker than that without magnet in figure (a). Then the dynamic damper vibrates greatly as shown in figure (b).

Table 1 Parameter of experimental system with gap 10mm and optimal system

\begin{tabular}{c|c}
\hline \hline $\begin{array}{c}\text { Experimental system } \\
\text { with Gap 10mm }\end{array}$ & Optimal system \\
\hline \multicolumn{2}{c}{$K=2.33 \mathrm{~kg}$} \\
\hline \multicolumn{2}{c}{$m=0.135 \mathrm{~kg}$} \\
\hline \multicolumn{2}{c}{$\gamma=0.0579$} \\
\hline \multicolumn{2}{c}{$\gamma=0.0539$} \\
\hline$k_{1}=1486 \mathrm{~N} / \mathrm{m}$ & $k_{1 \text { opt }}=1731 \mathrm{~N} / \mathrm{m}$ \\
\hline$k_{2}=-1184 \mathrm{~N} / \mathrm{m}$ & $k_{2 \text { opt }}=-1416 \mathrm{~N} / \mathrm{m}$ \\
\hline$k_{1}+k_{2}=302 \mathrm{~N} / \mathrm{m}$ & $k_{1 \text { opt }}+k_{2 \text { opt }}=315 \mathrm{~N} / \mathrm{m}$ \\
\hline$\gamma^{\prime}=0.204$ & $\gamma_{\text {opt }}^{\prime}=0.296$ \\
\hline
\end{tabular}

表 1 のパラメータ值を元に主系のコンプライアンスを数值シミュレーションによって求め, 最適動吸振器の場 合, ギャップ $10 \mathrm{~mm}$ の動吸振器の場合を実験結果と比較して図 10 に示す. 最適動吸振器のシミュレーションで は 2 つのピーク值がほぼ等しくなるが，ギャップ $10 \mathrm{~mm}$ のシミュレーションでは 2 次のピークが大きくなる. 表 1 において最適動吸振器単体の固有振動数 $\sqrt{\left(k_{1}+k_{2}\right) / m}$ が $7.69 \mathrm{~Hz}$ に対しギャップ $10 \mathrm{~mm}$ では $7.53 \mathrm{~Hz}$ と若干小さ いため, 1 次と 2 次ピークの間の反共振点が低振動数側に移動したことが主な原因である. 磁石の吸引力の非線 形性および動吸振器の等価損失係数の非線形性のために実験はギャップ $10 \mathrm{~mm}$ のシミュレーションとは大きく異 
なる結果となったが，偶然にも 1 次と 2 次のピークがほぼ等しく，かつ全体的に振幅が小さくなったものと考え ている.

磁石の吸引力や等価損失係数の非線形性についての影響を調べるため，インパクト加振の大きさを変えて測定 した主系のコンプライアンスを図 11 に示す. 加振力 $6.6 \mathrm{~N}$ のときが図 10 の実験結果に対応し, 動吸振器の効果が 十分に現れている. これに対し, 加振力が $4.1 \mathrm{~N}$ と小さくなると動吸振器の振幅が小さくなるため動吸振器のばね 定数が大きくなって反共振点が高振動数側に移動し，かつ等価損失係数が小さくなるため 1 次のピークが大きく なったと考えられる. 逆に加振力が $9.8 \mathrm{~N}$ と大きくなると動吸振器の振幅も大きくなり, 結果として動吸振器のば ね定数が小さくなって 2 次のピークが大きくなる. さらに等価損失係数が増えるために 2 次ピークの裙野が広く なり, 1 次のピークがそれに吸収されたようである. しかしながら図 8 の「磁石なし」の場合に比べると十分に 制振されているといえ，加振力の大きさが大幅に増大しないならば，通常状態における振幅を基準として設計し た動吸振器は大きな制振効果を示すと考えられる。

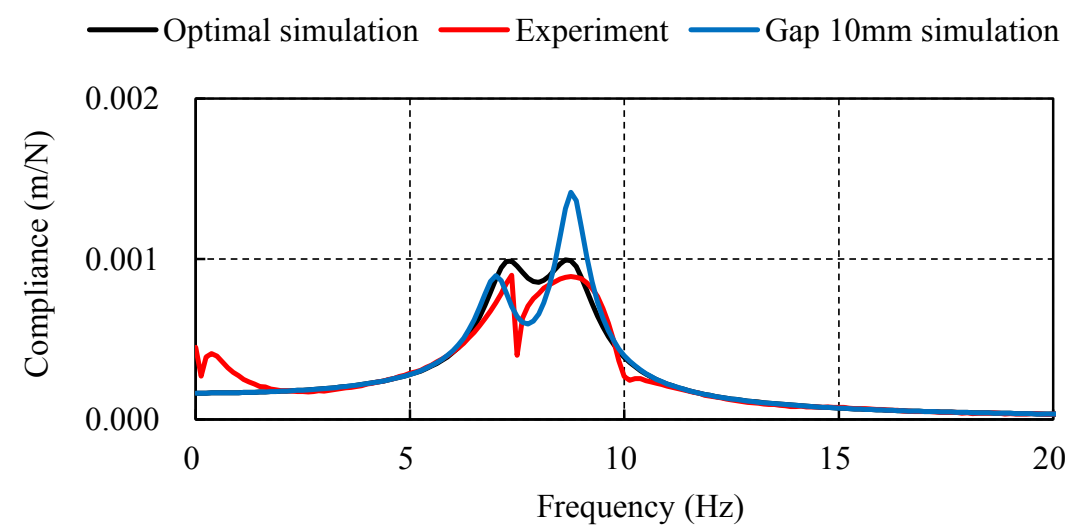

Fig.10 Simulation result of compliance in main system. The experiment and the simulation are almost in agreement.

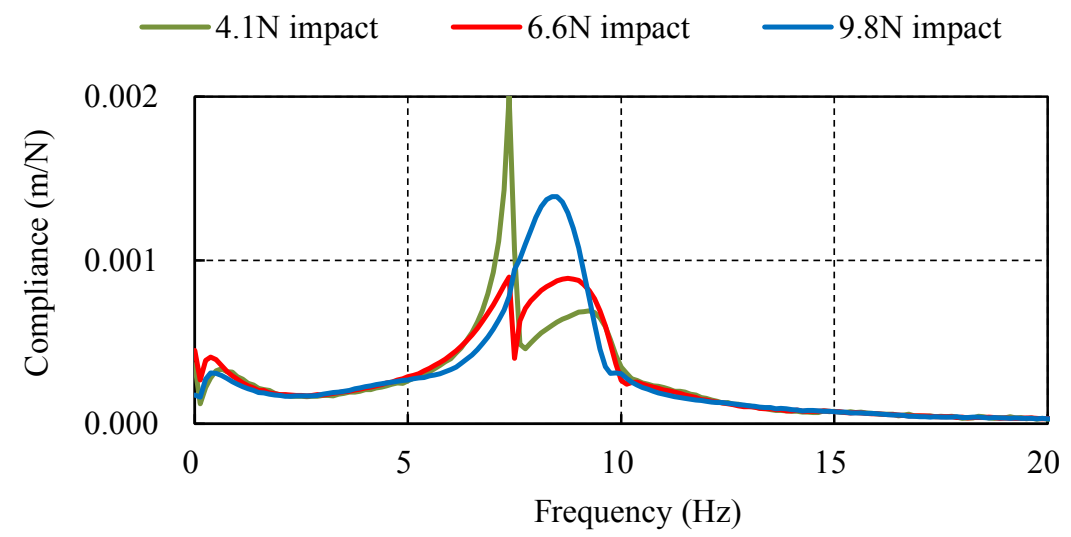

Fig.11 Experimental compliance for various impact force in main system. The compliance is affected by nonlinearity of the magnetic attraction force but the dynamic damper is sufficiently effective.

最後に制振合金以外の普通の金属を動吸振器のばねとして使用する場合を考える. 今回は表 1 のパラメータ值 を持つ系について考えたが，文献（五十嵐，2001）から炭素鋼の損失係数は制振合金の 1/10 以下になることを参 考に，ここで用いた制振合金の損失係数を $1 / 10$ に小さくし， $\gamma=0.00539$ として動吸振器の最適ば㸚定数を求め てみる. 動吸振器の最適条件から $k_{1 o p t}+k_{2 o p t}=315 \mathrm{~N} / \mathrm{m}$ かつ $\gamma_{o p t}^{\prime}=0.296$ になる必要があるので, $k_{1 o p t}=17307 \mathrm{~N} / \mathrm{m}, k_{2 o p t}$ $=-16992 \mathrm{~N} / \mathrm{m}$ が決定される. $k_{1 \text { opt }}$ と $k_{2 o p t}$ の值および $k_{1 \text { opt }}+k_{2 o p t}$ の值を比較すると $1 / 100$ 以下の精度で $k_{1 \text { opt }}$ と $k_{2 o p t}$ の ばねを製作する必要があり，これは簡単ではないことがわかる．かつ，磁石の吸引力の非線形性を考えると錘の 少しの変位でも負のばね定数 $k_{2 o p t}$ は益々強くなり,$k_{1 \text { opt }}$ と| $k_{2 o p t} \mid$ の值が近いことから錘が磁石に吸い寄せられるこ 
とが十分に考えられる．したがって実用的にはある程度の損失係数が必要になり，制振合金を使用することによ ってここに提案する動吸振器が容易に達成される.

\section{4. 結 言}

減衰の比較的大きな金属として制振合金が開発されているが，動吸振器のダンパとして用いるには減衰性能が それほど大きくない．本報では負のばね定数を利用することによって制振合金ばねの損失係数を等価的に大きく する方法を提案した，そして負のばねとして磁石の吸引力を利用した動吸振器を製作し，その制振効果を実証し た. 磁石の吸引力の非線形性のために動吸振器の制振効果はその振幅に依存するが, 動吸振器を設置しない場合 と比べると十分な制振効果が期待できる．また，動吸振器の場合に限らず，制振合金からなる構造物の減衰性能 を高めることにも応用でき,ダッシュポットのように油を使わないクリーンなダンパとしての利用も考えられる.

\section{文献}

五十嵐寿一編，騒音制御工学ハンドブック (資料編)，技報堂出版 (2001), pp.41-43.

岩田佳雄, 佐伯暢人, 小松㠃俊彦, 機械振動学, 数理工学社 (2017), pp.47-48.

前 義治, 制振合金の減衰機構と制振特性, 精密工学会誌, Vol.55, No.12 (1989), pp.2123-2126.

長松昭男編，ダイナミクスハンドブック，朝倉書店 (1993), p.150.

長松昭男編，制振工学ハンドブック，コロナ社 (2008), pp.31-33.

背戸一登，松本幸一，パソコンで解く振動の制御，丸善株式会社 (1999), pp.113-115.

浦田喜彦, 竹田生也, 粘弾性ばねを用いた動吸振器の設計法, 日本機械学会論文集 C 編, Vol. 61, No. 583 (1995), pp. 245-250.

\section{References}

Igarashi, J. ed., Handbook of Noise Control Engineering (Data book), Gihodo Shuppan Co., Ltd. (2001), pp.41-43 (in Japanese).

Iwata, Y., Saeki, M. and Komatsuzaki, T., Mechanical vibration, Suurikougaku-sha (2017), pp.47-48 (in Japanese).

Mae, Y., Damping mechanism and its characteristics of damping alloys, Journal of the Japan Society for Precision Engineering, Vol.55, No.12 (1989), pp.2123-2126 (in Japanese).

Nagamatsu, A. ed., Dynamics Handbook, Asakura Publishing Co., Ltd. (1993), p.150 (in Japanese).

Nagamatsu, A. ed., Handbook of Damping Technology, Corona Publishing Co., Ltd. (2008), pp.31-33 (in Japanese).

Seto, K. and Matsumoto, Y., Vibration control, Maruzen Publishing Co., Ltd. (1999), pp.113-115 (in Japanese).

Urata, Y. and Takeda, I., Method for design of dynamic vibration absorbers with viscoelastic springs, Transactions of the Japan Society of Mechanical Engineers, Series C, Vol.61, No.583 (1995), pp.245-250 (in Japanese). 